\title{
The Influence of Traditional Game Engklek with BERLIAN Method to Improve Problem Solving Skills
}

\author{
Iswinarti \\ University of Muhammadiyah Malang \\ iswinarti.tsi@gmail.com
}

\begin{abstract}
The purpose of this research was to know the effect of engklek traditional game with BERLIAN (Bermain-ExpeRiential-LearnIng-ANak) method to increase problem solving skills in school-age children. This research used experimental method with mixed subject design and 27-grade 4 students from 3 elementary schools as the subjects. The subjects will be divided into 3 experimental groups. Group $A$ and group B were given engklek payung and engklek pa'a game, while the control group was not given any treatment. The research instrument was a problem solving scale given before and after the treatment. The data were analyzed by using paired sample t-test. The result showed that there was a significant increase of problem solving ability in the experimental group $I(t=-11.179, p<0.01)$ and experimental group II $(t=-7.259$, $p<0.01)$ while in the control group, there was no significant increase $=$ $-1.270, p>0.05)$. Thus, it can be concluded that the traditional games, engklek payung and engklek pa'a, increase problem solving skills in school-age children.
\end{abstract}

Keywords: problem solving, engklek traditional game, BERLIAN method.

\section{INTRODUCTION}

Problem solving is an important ability in adults, but it needs to be understood how this ability develops in children. The use of a medium is an ideal way to learn problem solving in children because manual action can reveal how a child plans to achieve a goal.

The problem solving strategy is more effective on cooperative learning than conventional teaching. In Rudd's research (2010), it was found that the ability of problem solving is an important reason for learning mathematics. This study used heuristic reasoning and problem-solving strategies that were able to transfer the application of knowledge and showed that the group of students receiving the intervention had a significant improvement in problem solving abilities.

Problem solving is a process of working to get problem solutions and transforming the actual state into the desired one [8]. In this study, problem solving was aimed for school-age children as a learning strategy that makes students more active by training them to face various problems and find the solutions of the existing problems. Problem solving can also direct the ability of students both in the will, feeling, spirit, and the main thinking part in solving the problems. It can also encourage students to think systematically by confronting them with problems. By using problem solving skills, students learn to develop their mindset. Some students have problem solving skills through their self-confidence, level of achievement, and their ability to apply the knowledge in new situations to solve their problems.

The importance of problem solving in someone's life is to help someone find what they want and how to achieve it in the most effective way. A person's success in solving problems depends on how he is able to control his thinking ability in solving problems [7]. By thinking of a problem and looking at it from a different angle, so the right thing can arise when we think about it further.

Playing has the functions of problem solving, creativity, and imagination that can be transferred into life problems in real-world [10]. Someone who has problem solving skills will solve the problems and control himself well. In games, simple strategies may be considered as a means of developing students' problemsolving abilities in general.

Problem solving is one of important skills to be developed in school-age children. The ability is useful for success in making friends. Children who succeed in building friendships will be more invulnerable from emotional and mental difficulties. The ability of problem solving, especially the problem of social solving is needed by the children to overcome various problems that will be faced related to social and academic problems [5].

The traditional game, engklek, had therapeutic values [2]. The traditional game, engklek, trained the children to solve the problems that may appear during the game. Therefore, not only motor skills are featured in this game but there are also cognitive benefits that lead to problem solving skills. It can emerge when the children have to make a decision to choose the gaming option to throw, determine the strategy to win the game, and try to solve the problems when there are conflicts with other friends.

Traditional games provide stimulus for children in developing cooperation, adapting to interact in a positive way, developing empathy, obeying the rules, and respecting people around them [6]. In this case, game has a good impact in the development of emotions, problem solving, and social skills of children. 
The BERLIAN method is the application of experiential learning theory to children (BermainExpeRiential-LearnIng-Anak).Experiential learning is a concept or theory proposed by David Kolb in the early 1980s written in his book, published in 1984. After knowing the content of the values of learning problem solving in the traditional game, engklek, then it can be used as a basic for the preparation of modules to increase problem solving skills of children with the BERLIAN method.

This research aimed to eximine the effect of traditional game, engklek, on improving problem solving skills of school-age children.

\section{METHOD}

This research design is quasi experiment with control group, pre-test and post-test design. The independent variable in this study is the traditional game, engklek, and the dependent variable is problem solving skills.

The participants in this study were elementary school students in Malang. 27 subjects were grade 4-elementary school students, with the average age of 10.4 years. The researchers divide them into three groups. The division of the 3 groups consisted of experimental group I which received the traditional game, engklek payung, treatment, group II obtained engklek pa'a treatment, and group III was the untreated group or the control group. Each group consists of 9 children.

The instrument to measure pre-test and post-test in this research was problem solving scale consisting of 16 items compiled by Iswinarti (2015). This scale was tailor-made for the purposes of this study. The instrument was created in the form of a multiple-choice story that reveals how a child copes with problems encountered in everyday life. The answer option consists of three alternatives. Score 3 is given to a favorable option that supports problem solving abilities. Score 2 is given to a favorable option with a lower degree, while score 1 is given to a choice that indicates unfavorable or does not support problem solving abilities. The reliability of the scale was $\alpha 0.83$.

Engklek is a traditional game performed by jumping on one foot, using a stone ( $\mathrm{g} a \mathrm{cu}$ ) and a box that forms a pattern for its game media. The engklek payung game has a difficult degree of difficulty that the child must be right in stepping and doing the movement when moving from one box to another so that when switching the legs, they do not get out of the line. The engklek pa'a game that has difficulties in balancing gacu is placed on one part of the body in turn, so the child must think about the strategy so that when walking past, the box of gacu does not fall and steps out of the line.

\section{Research Procedure}

\section{Pre Treatment.}

At this stage the researchers conducted a test of the game and measured the instrument that will be used by the research subjects. The researchers tried out and observed to get a picture before the implementation of the research. It was about the time and the tools needed to complete the game, englek payung and engklek pa'a. Stage of Treatment.

This study will be conducted in three groups consisting of experimental group I, experimental group II, and control group. Initially, the whole group was given a pre-test to determine the taking of the research subject. Experimental group I was given engklek payung and experimental group II was given the treatment of engklek pa'a. Each group was given treatment in 4 sessions. The control group was not given any treatment.

\section{Final Stage.}

At this stage, post-test was conducted in three groups: experimental group I, experimental group II, and control group. The final step of this research is to analyze the data.

\section{RESULT}

The first data analysis is to examine the differences in pre-test results of the three groups. The results showed no difference in problem solving skills among experimental group I, experiment II, and control group. After that, paired sample t-test was done to test the difference between pre-test and post-test of problem solving skills in the three groups. The results are as listed in Table 1.

Table 1. Result of $\mathrm{t}$-test between pre-test and post-test

\begin{tabular}{lccc}
\hline \multicolumn{1}{c}{ Group } & $\begin{array}{c}\text { Mean } \\
\text { Differences }\end{array}$ & t & $\begin{array}{c}\text { Sig (2- } \\
\text { talled) }\end{array}$ \\
\hline Engklek Payung & -9.25 & -4.73 & 0.00 \\
\hline Engklek Pa'a & -14.16 & -14.22 & 0.00 \\
\hline Control & -0.66 & -0.55 & 0.24 \\
\hline
\end{tabular}

Based on the results of data analysis, it can be concluded that:

1. The traditional game, engklek payung, can improve problem solving skills of the children.

2. The traditional game, engklek $p a^{\prime} a$, can increase problem solving skills of the children.

3. There was no increasing problem solving skills in control group.

This study aims to examine the effect of traditional games with BERLIAN method on problem solving ability of children. The results showed that the traditional games, engklek payung and engkek pa'a, can improve problem solving ability of the children.

The research findings support the previous research, stating that generally, traditional games can increase children's problem solving skills [3]. The traditional game which was analyzed was gembatan, while this research studies engklek [3].

In engklek payung and engklek pa'a, every player must understand the rules of the game so that they can comply with the existing regulations. The process is 
related to the aspects of problem solving: (1) finding and understanding the problems. In this case, the subjects will be asked to find the difficulties or mistakes made by themselves or mistakes made by their friends so that the subjects can understand the problems in the game; (2) developing a problem-solving strategy. After the subject encounters an error or difficulty facing the subject's will, they will be asked to find a solution or strategy so that in the next opportunities, they can play better and no more errors occur. The subjects who will also use the strategy in the game can be a winner; (3) exploring the solution. Here, the subjects are able to apply the solutions or strategies used [9].

The giving of reflection (BERLIAN METHOD) aims to know the extent to which the subjects understand the purposes and benefits of the game. Feedback process or reflection was not only done once. At the end of each session, it would be given feedback, so that the subjects can find a solution of the existing difficulties and learn from previous mistakes. By being given feedback, the children were able to learn and find the problems faced so that they were also directed to solve the problems. The BERLIAN method is a method that can accelerate the planting of problem solving values to the children after they play engklek.

Generally, games have therapeutic values to help children's problems. Engklek has five therapeutic values, one of those is problem solving [2]. Playing has the functions of problem solving, creativity, and imagination that can be realized into real life [10]. By having problem solving function, individuals can solve their problems better.

\section{CONCLUSION}

The traditional games, engklek payung and engklek $p a ' a$, with BERLIAN method have the effect of improving problem solving skills in school-age children. The research results can be recommended to be implicated in character education for children.

\section{REFERENCES}

[1] Fawcett, L \& Garton, A. The effect of peer collaboration on children's problem-solving ability authors. British Journal of Educational Psychology, 75, 157-169. 2005.

[2] Iswinarti. Nilai-nilai terapeutik permainan tradisional engklek pada anak usia sekolah dasar. Humanity, 6(1), 41-44. 2010.

[3] Iswinarti, Ekowarni, E., Adiyanti, MG., \& Hidayat, R. The influence of traditional game with experiential learning on social competence. International Journal of Recent Scientific Research, 4(7), 10144-10155. 2016.

[4] Kolb. D. Experiential learning: experience as the source of learning and development. New Jersey : Prentice Hall, Inc. 1984.

[5] Kostelnik, M. J. Gregory, K. M. Soderman, A. K. \& Whiren, A. P. Guilding childern social development and learning $7^{\text {th }}$ edition. Belmont : Wadworth, Cengage Learning. 2012.

[6] Kurniawati, E. Program bimbingan untuk mengembangkan keterampilan sosial anak melalui permainan tradisional. Jurnal Ilmu Pendidikan, 4, 97-114. 2011.

[7] Lidnillah, D. A. M. Strategi pembelajaran pemecahan masalah di sekolah dasar. Jurnal Pendidikan Dasar, 10. 2008.

[8] Oemar, dan Weney. Enquiry Discovery pendekatan pemecahan masalah dalam pengajaran IPS. Jakarta: Proyek Pengembangan Pendidikan Guru (P3G) Depdikbud, 7.1980.

[9] Santrock, J. W. Life span development: perkembangan masa hidup edisi 5 jilid I. Jakarta: Erlangga. 2002.

[10] Smith, B. S. Children forklore: a source book. Logan, Utah: Utah University Press. 1999.

[11] Zigmont, J. J., Kappus, L. J., Sudikop, S. N. Theoritical foundations of learning through simulation. Semin Perinatol. 35. 47-51. 2011. 